\title{
Peningkatan Kemampuan Komunikasi Bahasa Inggris di Era Globalisasi kepada Para Pemuda Karang Taruna di RW 05 Desa Karang Asem Barat-Citeureup Kabupaten Bogor
}

\author{
Bejo Sutrisno*, Suhendar, Mohamad Mansur, Budiarto, Mukhlasul Fasikh \\ Sastra Inggris, Sekolah Tinggi Bahasa Asing IEC Jakarta \\ *bejo@stibaiec-jakarta.ac.id
}

\begin{abstract}
Abstrak
Tujuan dari kegiatan ini adalah: (1) melatih peserta tentang komunikasi Bahasa Inggris yang baik dan benar baik secara tata bahasa maupun secara pemilihan kata yang tepat dan (2) melatih kelancaran komunikasi Bahasa Inggris untuk memahami ketrampilan yang ada di tiap komponen pelatihan yang terdiri dari latihan menyimak, penggunaan struktur Bahasa yang baik dan benar dalam tulisan, pemahaman dalam membaca, dan kemahiran dalam berbicara. Metode yang digunakan adalah metode pendekatan komunikatif yang melatih peserta didik untuk memahami ketrampilan yang ada di tiap komponen pelatihan yang terdiri kemampuan berbicara, menulis, membaca dan mendengar. Hasil dari kegiatan ini menunjukan bahwa peserta pelatihan mengalami perubahan yang positif baik dari segi kelancaran, pemehaman, penggunaan struktur Bahasa dan kosa kata.
\end{abstract}

Kata kunci: berbicara, kemampuan komunikasi, menyimak, pendekatan komunikatif.

\section{PENDAHULUAN}

Dengan semakin canggihnya dan berkembangnya teknologi memudahkan setiap individu untuk berinteraksi dengan dunia luar, sehingga kebutuhan akan kecakapan berbahasa Inggris sangat diperlukan baik tertulis maupun berbicara di mana kita bisa berkomunikasi dengan siapa saja yang ada di belahan dunia. Empat ketrampilan berbahasa Inggris yaitu berbicara, dan menulis, sebagai ketrampilan produktif (productive skills) dan mendengarkan dan membaca sebagai ketrampilan reseptif (receptive skills) yang harus dimiliki setiap individu perlu didukung dengan tiga komponen bahasa lainnya yaitu struktur (grammatical structure), pengucapan (pronunciation) dan kosa kata (vocabulary) untuk menguasai bahasa secara efektif dan komprehensif.

Beberapa permasalahan yang dihadapi mitra pengabdian adalah kurangnya kemampuan mereka dalam komunikasi bahasa Inggris baik secara lisan maupun tulisan yang dapat menunjang kegiatan kerja sehari-hari. Salah satu komponen Bahasa yang menjadi hambatan kurang percaya diri dari peserta adalah kelamahan dalam penggunaan tata Bahasa (Grammar) dalam Bahasa Inggris. Dbagaimanapun juga tata Bahasa sangat diperlukan dalam komunikasi Bahasa Inggris untuk kesempurnaan dalam komunikasi. Aturan-aturan penggunaan tata Bahasa perlu dibiasakan dalam komunikasi. Hal ini seperti yang diungkapkan oleh Leech (2006), "One way of describing grammar is as a set of rules that allow us to put words together in certain ways, but not in other ways". Bahwa satu cara dalam mendiskripsikan tata Bahasa adalah sebagai seperangkat aturan yang untuk Menyusun rangkaian kata-kata dengan aturan-aturan yang telah ditentukan. 
Demikian juga penggunaan kala (tenses) juga sangat dibiasakan dalam komunikasi Bahasa Inggris. Kala (tenses) biasanya didefinisikan sebagai rangkaian hubungan antara waktu, tindakan dan keadaan. (Bauer, 1983).

Selain penguasaan struktur Bahasa, peserta juga perlu diberi pemahaman terhadap penguasaan terhadap kosakata Bahasa Inggris. Dengan penguasaan kosakata maka akan memudahkan peserta dalam komunikasi. Hal ini seperti yang diungkapkan oleh Tarigan (1993:23), bahwa kosakata selain untuk meningkatkan kuantitas dan kualitas perbendaraan kata untuk para siswa, juga bertujuan untuk meningkatkan kemampuan dalam berkomunikasi, meningkatkan kemampuan mental, meningkatkan perkembangan konseptual, mempertajam proses berfikir kritis, dan memperluas cakrawala pandangan hidup para siswa.

Dampak lainnya adalah kurangnya kesempatan atau pengalaman untuk melaksanakan kegiatan komunikasi bahasa Inggris sehingga ketika mereka mendapatkan peluang mengikuti seminar atau workshop di dunia internasional mereka mengalami kesulitan dalam membuat materinya, sehingga masih memerlukan bantuan penerjemah dari institutusi lain. Begitu pula ketika para pegawai mendapatkan peluang untuk mendapatkan program bea siswa ke luar negeri, mereka memiliki hambatan untuk memenuhi persyaratannya, yaitu diantaranya kemampuan komunikasi bahasa Inggris baik secara lisan maupun tulisan. Dengan demikian kesempatan untuk memperoleh pendidikan dan pengalaman yang lebih baik di dunia internasional menjadi terhambat.

Dengan mempertimbangkan masalah yang telah dipaparkan di atas, maka dalam proses pengajaran harus dapat memperhatikan peran sebagai pengajar (teacher) untuk bisa membuat peserta didik berhasil dan mampu dalam menyerap ilmu dan pengetahuannya. Hal ini sesuai yang kutip dari Wilson (2006), "Teaching is intellectual work; that teachers have a range of roles, including information deliverer and team coach." Bahwa pengajaran merupakan karya intelektual yang memiliki peran masing-masing dalam kerja tim termasuk juga menyampaikan informasi kepada peserta didik. Sementara menurut Aggaraval (2009) bahwa penhajaran adalah suatu petunjuk bagi siswa-siswa untuk mempelajari hal yang benar, sikap yang benar dan tata cara tingkah laku yang benar dan melakukan sesuatu yang sesuai penggunaannya.

Dalam kegiatan Pengabdian kepada Masyarakat ini tidak sebatas hanya memberikan keterampilan berbahasa Inggris namun juga memberikan dorongan dan motivasi cara menggunakan Bahasa Inggris dengan baik dan benar dan motivasi terhadap pentingnya menguasai salah satu Bahasa asing di jaman yang terus berkembang.

\section{METODE PELAKSANAAN}

\section{Tujuan dari Pengabdian kepada Masyarakat}

Tujuan dari kegiatan ini adalah: (1) memberikan pengetahuan dan pemahaman tentang komunikasi Bahasa Inggris yang baik dan benar baik secara tata bahasa atau gramatika (grammatically correct) maupun secara pemilihan kata yang tepat (word choice) dan (2) melatih kelancaran komunikasi Bahasa Inggris untuk memahami ketrampilan (skill) yang ada di tiap komponen pelatihan yang terdiri dari latihan menyimak (listening comprehension), penggunaan struktur Bahasa yang baik dan benar dalam tulisan (structure and written expression), pemahaman 
dalam membaca (reading comprehension), dan kemahiran dalam berbicara (speaking skill).

\section{Tempat dan Waktu}

Kegiatan Pengabdian kepada Masyarakat dilaksanakan di Desa Karangasem Barat, Citeureup, Bogor yang dilaksanakan dari bulan September dan berakhir di bulan November 2020.

Metode yang digunakan adalah metode pendekatan komunikatif ( $a$ communicative approach) yang melatih peserta didik untuk memahami ketrampilan (skill) yang ada di tiap komponen pelatihan yang terdiri kemampuan berbicara, menulis, membaca dan mendengar (four language skills). Segala kegiatan selama pengabdian masyarakat peserta pelatihan Bahasa Inggris dituntut untuk terus berkomunikasi secara lisan dan langsung melalui kegiatan tanya jawab/dialogue dan diskusi, problem solving, dan kerja kelompok.

\section{Indikator Keberhasilan}

Keberhasilan Pengabdian kepada Masyarakat di desa Karang Asem Barat, Citeureup adalah: (1) peserta mampu diarahakan untuk dapat meningkatkan penguasaan kosakata yang aplikatif, dalam peningkatan kemampuan komunikasi bahasa Inggris; (2) Peserta mampu meningkatkan kemampuan membaca dan mendengar; (3) Peserta pelatihan mampu diarahkan untuk lebih meningkatkan kemampuan berbicara, dan menulis; dan (4) Peserta pelatihan mampu diarahkan untuk berani mengucapkan dan mempraktekkan komunikasi Bahasa Inggris secara lisan dan tulisan.

Dengan mengacu pada indicator keberhasian di atas diharapkan proses pelaksanaan kegiata Pengabdian kepada Masyarakat dapat terukur dan dilaksanakan sebaik-baiknya untuk mencapai tujuan. Karena peserta dari kalangan latar belakang yang berbeda sehingga perlakuan dalam latihan sangat berbeda dengan yang dilakukan untuk mahasiswa dan perlu pendekatan khusus untuk bisa mencapai tingkat keberhasilan yang diinginkan.

\section{Metode Evaluasi}

Evaluasi terhadap kegiatan Pengabdian kepada Masyarakat ini dilakukan melalui diskusi antar sesama kelompok latihan komunikasi bahasa Inggris untuk memperoleh masukan dari khalayak sasaran untuk perbaikan kegiatan Pengabdian kepada Masyarakat pada kegiatan selanjutnya.

\section{Peserta Kegiatan}

Peserta kegiatan pada Pengabdian kepada Masyarakat ini berjumlah 10 orang yang merupakan pemuda dan pemudi karang taruna yang berdomisili di daerah tersebut dengan latar belakang Pendidikan yang bervariasi dari lulusan SMP, SMA dan masih mahasiswa.

\section{HASIL DAN PEMBAHASAN}

Setiap kegiatan dilakukan secara bersama-sama dengan system berbagi tugas sesuai dengan bidang keterampilannya dan pendampingan selama proses pengajaran dan 
pembelajaran dengan pendekatan komunikasi. Adapun waktu dan proses kegiatannya dapat terlihat pada Tabel 1 .

Tabel 1. Kegiatan Pelatihan

\begin{tabular}{|c|c|c|c|}
\hline $\begin{array}{l}\text { Perte- } \\
\text { muan }\end{array}$ & $\begin{array}{l}\text { Waktu dan } \\
\text { Tanggal }\end{array}$ & Materi & $\begin{array}{c}\text { Fasili- } \\
\text { tator }\end{array}$ \\
\hline $1 \& 2$ & $\begin{array}{c}02 \& 04 \\
\text { September } \\
2020 \\
08.00-09.00\end{array}$ & $\begin{array}{l}\text { Introducing yourself; introducing someone, } \\
\text { checking information, asking about someone; } \\
\text { exchanging personal information. }\end{array}$ & Tim \\
\hline $3 \& 4$ & $\begin{array}{c}09 \& 11 \\
\text { September } \\
2020 \\
08.00-09.00\end{array}$ & $\begin{array}{l}\text { Describing work and school; asking for and } \\
\text { giving opinions, talking about daily schedule. }\end{array}$ & Tim \\
\hline $5 \& 6$ & $\begin{array}{c}16 \& 18 \\
\text { September } \\
2020 \\
08.00-09.00\end{array}$ & $\begin{array}{l}\text { Talking about prices, giving oipinion, talking } \\
\text { about preferences, making comparisons, buying } \\
\text { and selling things. }\end{array}$ & Tim \\
\hline $7 \& 8$ & $\begin{array}{c}23 \& 25 \\
\text { September } \\
2020 \\
08.00-09.00\end{array}$ & $\begin{array}{l}\text { Talking about likes and dislaikes, giving } \\
\text { opinions, making invitations and execuses. }\end{array}$ & Tim \\
\hline $9 \& 10$ & $\begin{array}{c}02 \& 07 \\
\text { Oktober } 2020 \\
08.00-09.00\end{array}$ & $\begin{array}{l}\text { Talking about families, and family members, } \\
\text { excganging information about the present; } \\
\text { describing family life }\end{array}$ & Tim \\
\hline $11 \& 12$ & $\begin{array}{c}09 \& 14 \\
\text { Oktober } 2020 \\
08.00-09.00\end{array}$ & $\begin{array}{l}\text { Asking about and describing raotines and } \\
\text { exercise; talking about frequency; talking about } \\
\text { abilities. }\end{array}$ & Tim \\
\hline $13 \& 14$ & $\begin{array}{c}16 \& 21 \\
\text { Oktober } 2020 \\
08.00-09.00\end{array}$ & $\begin{array}{l}\text { Talking about past events; giving opinions } \\
\text { about past experiences; talking about } \\
\text { vacations. }\end{array}$ & Tim \\
\hline $15 \& 16$ & $\begin{array}{c}23 \& 28 \\
\text { Oktober } 2020 \\
08.00-09.00\end{array}$ & $\begin{array}{l}\text { Asking about and describing locations of } \\
\text { plaecess; asking about and describing } \\
\text { neighbourhood; asking about quantities. }\end{array}$ & Tim \\
\hline $17 \& 18$ & $\begin{array}{c}04 \& 06 \\
\text { November } \\
2020 \\
08.00-09.00\end{array}$ & $\begin{array}{l}\text { Asking about and describing peoples's } \\
\text { appearance; identifying people. }\end{array}$ & Tim \\
\hline $19 \& 20$ & $\begin{array}{c}11 \& 13 \\
\text { November } \\
2020 \\
08.00-09.00\end{array}$ & $\begin{array}{l}\text { Describing past experinces; making plans, } \\
\text { exchanging information about past experiences } \\
\text { and events. }\end{array}$ & Tim \\
\hline $21 \& 22$ & $\begin{array}{c}18 \& 20 \\
\text { November } \\
2020 \\
08.00-09.00\end{array}$ & $\begin{array}{l}\text { Asking about and describing cities; asking for } \\
\text { and giving suggestions, talking about travel and } \\
\text { torism. }\end{array}$ & Tim \\
\hline $23 \& 24$ & $\begin{array}{c}25 \& 27 \\
\text { November } \\
2020 \\
08.00-09.00\end{array}$ & $\begin{array}{l}\text { Talking about health problem, asking for and } \\
\text { giving advise; making request; asking for and } \\
\text { giving suggestion. }\end{array}$ & Tim \\
\hline
\end{tabular}


Pada pertemuan pertama dan kedua rata-rata setiap peserta terlihat termotivasi terhadap kegiatan belajar bahasa Inggris terutama pada pokok bahasan percakapan meskipun beberapa di antara mereka masih enggan untuk mempertanyakan jika menjumpai kesulitan namun terus berlatih dengan teman-temannya. Dalam situasi seperti ini tim atau fasilitator selalu memberikan dorongan kepada setiap peserta untuk berani bertanya baik kepada teman-temannya maupun kepada tutornya. Contoh percakapan singkat pada pertemuan pertama adalah sebagai berikut.

\section{Tutor : What's your fulname? \\ Peserta 1 : Asep Sopian \\ Tutor : Please repeat after 'My fulname is ... \\ Peserta 1 : Please repeat after 'My fulname is Asep Sopian}

Tutor menanyakan pertanyaan yang sama kepada beberapa peserta yang lain untuk bisa memberikan jawaban dengan benar. Proses tanya jawab diberikan secara bergantian untuk saling praktek melakukan tanya jawab tentang tema introduction.

Kemudian salah satu dari tutor mencoba mengembangkan topik pembahasan dengan menanyakan kepada salah satu peserta tersebut.

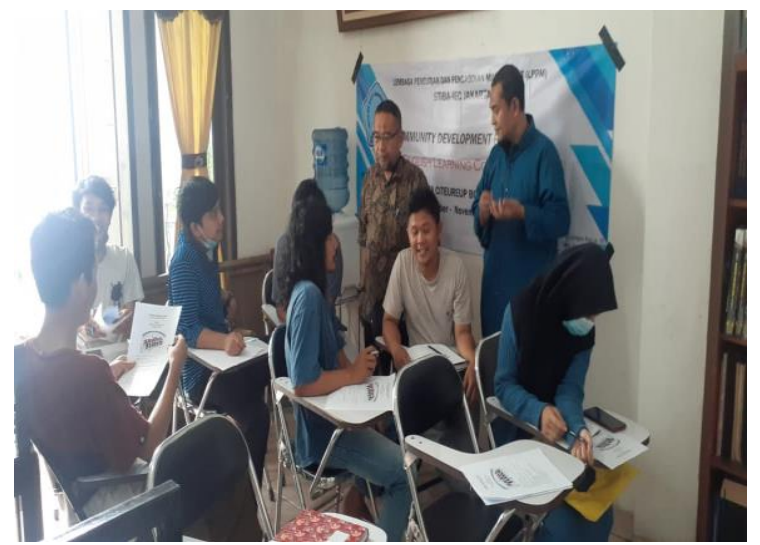

Gambar 1. Tutor menerangkan dan Memberikan Motivasi pada Pertemuan Pertama.

Langkah awal yang dilakukan pada pertemuan ini adalah memberikan motivasi kepada setiap peserta untuk terus percaya diri dalam berlatih dan memberikan pemahaman tentang arti pentingnya belajar komunikasi bahasa Inggris di jaman yang terus berkembang.

Pada pertemuan-pertemuan berikutnya para peserta sudah mulai terbiasa dan lebih akrab dengan tutor dan peserta yang lain serta lebih percaya diri dalam kegiatan komunikasi bahasa Inggris.

Berdasarkan pengamatan yang dilakukan oleh salah satu tim pelaksana Pengabdian kepada Masyarakat ada beberapa temuan dalam kegiatan tersebut yang di antaranya adalah:

Berdasarkan catatan lapangan yang dilakukan oleh para pelaksana kegiatan melalui lembar observasi tutor dalam kegiatan belajar peserta dan kelompok dijumpai beberapa poin penting yang diantaranya adalah:

a) Pelaksanaan. Secara garis besar pelaksanaan pada proses belajar dengan cukup baik meskipun masih ada beberapa kendala dalam meningkatkan kepercayaan 
diri dan membuat lebih aktif kepada setiap peserta karena keterbatasan kemampuan tata Bahasa dan kosa kata Bahasa Inggris. Namun semua itu adalah suatu proses yang di kemudian hari bisa ditingkatkan.

b) Peran dalam Kelompok. Masing-masing peserta saat dibuat berkelompok untuk mempraktikan komunikasi dalam Bahasa Inggris di dalam kelompoknya masing-masing, di sini melalui pengamatan masih menjumpai peserta yang belum optimal dalam keaktifannya.

c) Kemampuan menyampaikan gagasan. Pada poin ini masih terlihat peserta yang belum berani untuk menyampaikan pendapatnya dalam saat diminta untuk bertanya dalam Bahasa Inggris, hal ini diakibatkan karena kurang terbiasa untuk mengemukakan pendapatnya dalam Bahasa Inggris.

d) Memotivasi anggota lain. Belum nampak secara keseluruhan setiap peserta untuk saling memberikan motivasi kepada peserta yang lainnya. Meski demikian sudah terlihat beberapa peserta yang nampak semangat dan terus berlatih.

e) Interaksi sesame peserta. Masih terdapat beberapa peserta yang belum bisa berinteraksi secara maksimal. Masih dijumpai beberapa siswa yang terlihat pasif. Namun demikian mereka tetap bisa berinteraksi dengan peserta yang lain saat praktik berbicara dalam kelompoknya meskipun hanya sebatas memberi tanggapan sederhana.

Dengan hasil pengamatan di atas dan dengan terbatasnya kegiatan selama Pengabdian kepada Masyarakat setidaknya bisa memberikan pengetahuan yang memadai kepada para pemuda di tempat dilakukannya kegiatan tersebut.

\section{SIMPULAN}

Berdasarkan hasil kerja tim dan juga pengamatan selama proses Pengabdian kepada Masyarakat maka dapat disimpulkan poin-poin sebagai berikut.

Dari segi struktur bahasa peserta sudah mulai bisa memberikan gagasangagasannya yang akurat dan sesuai dengan topik pembahasan meskipun masih dijumpai beberapa peserta yang belum sepenuhnya menuangkan gagasangagasannya dengan rinci, tepat dan akurat. Sementara dari segi pembentukan kaliama masih ada beberapa peserta yang masih belum bisa mengorganisasikan kalimat-kalimat tersebut dengan teratur.

Dari segi penggunaan kosa kata, setiap peserta sudah mulai bisa menentukan kata-kata mana yang sesuai dengan tema yang dibicarakan dan mudah dipahami. Secara keseluruhan mulai ada peningkatan dalam penggunaan kosa kata meskipun masih ada beberapa yang masih terbatas terhadap penguasaan kosa kata.

Dari segi bahasa, para peserta sudah mulai bisa menggunakan struktur bahasa dengan benar, dan bisa menggunakan unsur-unsur bahasa seperti penggunaan kala (tenses), susunan kata (word order), article, kata depan (preposition) dan yang lainya dengan benar. Akan tetapi masih terdapat beberapa peserta yang masih mengalami kesulitan untuk menggunakan unsur-unsur tata bahasa tersebut.

\section{DAFTAR PUSTAKA}

Aggaraval, J. C. (2009). Principle, Method, and Technique of Teaching. New Delhi: Vikas Publishing House. 
Bauer, L. (1983). English Word-Formation. New York: Cambridge University Press.

Leech, G. (2006). English Grammar for Today, A New Introduction. New York: Palgrave Macmillan, 2nd edition.

Tarigan, H. (1993). Pengajaran Kosakata. Jakarta: Rineka Cipta

Wilson, P. (2006). Theories of Learning and Teaching. Washington: National Education Association. 